\title{
Study to assess determinants of domestic violence among women in urban slum of Mumbai
}

\author{
Dr. Tejashri D. Kambli ${ }^{1}$,Dr. Y. K. Kazi ${ }^{2}$,Dr. Y. B. Chavan ${ }^{3}$,Dr. G.D. Velhal ${ }^{4}$ \\ ,Dr. R. Y. Aras ${ }^{5}$ \\ ${ }^{l}$ Ex-Resident, T.N.M.C, Programme Officer, NACO. \\ ${ }^{2}$ Assistant Professor, T.N.M.C \\ ${ }^{3}$ Addl. Professor, G.S.M.C, KEM Hospital. \\ ${ }^{4}$ Addl. Professor, T.N.M.C \\ ${ }^{5}$ Ex. Prof. \& H.O.D, T.N.M.C \\ Department of Community Medicine \\ Institution: - T. N. Medical College \& B.Y.L. Nair Ch. Hosp, Mumbai, MUHS Nashik, India
}

\begin{abstract}
Violence against women could be physical, mental or sexual. It reflects inequities between men and women and compromises health, dignity, security \& autonomy of the victims. The present study was carried out at the Urban Health Centre \& included all married women in the reproductive age, to study various factors associated with violence, and the decision making power of the women.

Objectives:

1. To identify socio-cultural and demographic factors related to domestic violence.

2. To assess health status of these women.

3. To assess decision making power of women and its relationship with domestic violence.

Methodology: A cross-sectional, descriptive, epidemiological study was carried out at Urban Health Centre, Govandi, field practice area affiliated to the Department of Preventive \& Social Medicine, Topiwala National Medical College, Mumbai, during the period from $1^{\text {st }}$ February $2008-31^{\text {st }}$ March 2008. Study population included married women who experienced domestic violence, in the age group 15-45 years, attending general OPD $(n=105)$. Women were enquired about the type of violence faced by them, their perpetrators, the perceived risk factors and their decision making power in the family. Data was analyzed using SPSS 11.5.

Results :

Women who experienced violence were included in the study ( $n=105)$. Most of them (82.86\%) were Muslims, illiterate(53.34\%) and were in the age group 26 - 35 years(57.14\%). The violence faced by them was mostly Verbal(71.42\%) and Physical violence (48.57\%), with perpetrators being mostly their husbands' and Mother-in - law. These women did not have any power in decision making in the family.
\end{abstract}

Key Words:

Domestic Violence, Decision making power, Urban Health Centre, Women, Risk factors.

\section{Introduction}

Violence against women is a global problem in all communities of the world. Violence affects the lives of millions of women worldwide, in all societies. It hinders the basic rights of women as a human being. It is only recently that violence against women has been recognized as violation of basic human rights. According to available statistics from around the globe, one out of every three women has experienced violence in an intimate relationship at some point in her life. This is an average based on available national surveys across industrialized and developing countries (World Health Organization 1997). In National Family Health Survey -3 2005-06 estimated prevalence of overall violence experienced by women as $35 \%$ in India[1].

The acts of violence against members of the household, whether wife or child, were perceived as discipline, and essential for maintaining the rule of authority within the family. In the last two decades, the Indian women's movement has contributed to a growing public awareness about violence against women. Domestic violence against women must be perceived as a global problem rather than a private issue embedded in family. It is unfortunate that this issue is neglected and ignored as a topic of study so far and is always concealed under the myth of private matter.

AIM

To study the determinants of domestic violence among married women in an urban slum of Mumbai. Objectives

1. To identify socio cultural and demographic factors related to domestic violence.

2. To study health status of these women. 
3. To assess decision making power of women and its relationship with domestic violence.

\section{Methodology}

A cross sectional, descriptive, epidemiological study was carried out at the Urban Health Centre, Shivaji Nagar, Govandi, affiliated to the Department of Preventive \& Social Medicine, T.N. Medical College, Mumbai during the period from February to March 2008. There were total of 2438 patients attending the Urban Health Centre during the period February to March 2008. Out of which 789 were females between the age group 18 - 45 years( Adults in Reproductive age group) \& 350 were married among them. 125 females gave history of violence. Out of these, 20 females did not agree to participate in the study. So, the total sample for this study was 105.Consent was taken from all the women. Data was collected with the help of a Pretested, preformed, semi structured interview schedule by the author and it included details regarding their age, socioeconomic structure, education, family type . The various types of violence faced by them, their perpetrators, and the perceived risk factors of violence were also enquired into. The women were also asked if they suffered from any health problem. Their Height and Weight was taken and BMI calculated and the women were classified whether they were malnourished or no. Their Decision making capacity in their household was enquired into

Data was analyzed using the SPSS package version 11.5. Graphs \& Tables were drawn where required.

\section{Results:}

The number of women interviewed in this study were 105. Table.1 shows the demographic profile of the respondents.17.14\% (18) were Hindus and $82.86 \%$ (87) were Muslims, as this area is Muslim- dominated.

$57.14 \%$ (60) of the women were in the age group $26-35$ years, ( Mean age $=29$ years \& S.D $=6.04$ years). 53.34\% (56) of the women were illiterate. Most of the women in the study i.e. $84.76 \%(89)$ were housewives and had no source of income, as against $15.23 \%$ (16) who had some source of income. According to the type of family, $60 \%$ (63) of the females were living in Nuclear families. All the women in the study revealed some form of violence. Table. 2 shows the various determinants of violence. The most common violence faced by the women were Verbal violence among $71.42 \%$ (75) of women, followed by Physical violence among $48.57 \%(51)$ of women. There were multiple types of violence faced by each women. $28.57 \%(30)$ of the women faced violence daily \& $48.57 \%(51)$ of them faced violence weekly. Most common kind of physical assault is grade I in $56.86 \%$ (29) i.e. slapping, pushing, shoving, throwing objects followed by grade II in $31.37 \%(16)$ i.e.

kicking, biting and then grade III i.e. chocking, strangling, use of knife or stick for beating in $11.76 \%(6)$ of respondents[2]. The perpetrators of violence were mostly husbands' in $85.71 \%(90)$ of cases and mother's in law $29.52 \%(31)$. Some of the victims were abused by both their husbands' as well as their mothers'in-law. The Perceived risk factor for violence was mostly Poverty in $29.52 \%$ (31) of women and Addiction of husband's in $27.61 \%$ (29) of women(Table 3) The triggering factor for violence was Not giving food in time in $30.47 \%$ (32) and asking for money in $31.42 \%$ (33) of women(Table4). Only $51.42 \%$ (54) of women showed some form of retaliation after violence, while $48.57 \%(51)$ women did not react and silently suffered at the hands of the perpetrator.. These women who faced violence at the domestic front had various health problems ranging from Body ache to Back ache to Leucorrhea(Table.5). The Nutritional Status of these women was also hampered, as $28.5 \%$ (30) of the women were shown to be having lower BMI(Table.6).

The Decision making capacity of the women were enquired into and it was seen in this study (Table. 7 \& Table. 8) that daily things as what to cook, the decision was taken by the females in $80 \%$ (84) of the women. But, important decision as Purchasing major household items is taken by Husband's in 70.48\%(74) of women. $53.33 \%$ ( 56) of the women were not allowed to keep money with themselves. $68.58 \%$ (72) of the women were either forced to leave or were prevented from taking up jobs.

Tables .

Table 1: Demographic Profile of Respondents

\begin{tabular}{|l|l|}
\hline Age Group & $32(30.48 \%)$ \\
$18-25$ & $60(57.14 \%)$ \\
$26-35$ & $13(12.38 \%)$ \\
$36-45$ & \\
\hline Religion & $18(17.14 \%)$ \\
Hindu & $87(82.86 \%)$ \\
Muslim & \\
\hline Education & $56(53.34 \%)$ \\
Illiterate & $34(32.38 \%)$ \\
Primary & $13(12.38 \%)$ \\
Secondary & $1(0.95 \%)$ \\
Higher Secondary & $1(0.95 \%)$ \\
Graduate &
\end{tabular}




\begin{tabular}{|l|l|}
\hline Occupation & $89(84.76 \%)$ \\
Not Earning & $16(15.24 \%)$ \\
Earning & \\
\hline Type of Family & $63(60 \%)$ \\
Nuclear & $22(21 \%)$ \\
Joint & $20(19 \%)$ \\
\hline 3 Generation & \\
\hline
\end{tabular}

Table 2: Determinants of Violence

\begin{tabular}{|l|l|}
\hline Types of Violence & \\
Physical & $51(48.57 \%)$ \\
Sexual & $30(28.57 \%)$ \\
Verbal & $75(71.42 \%)$ \\
Economic & $59(56.19 \%)$ \\
\hline $\begin{array}{l}\text { Types of Physical } \\
\text { Violence }\end{array}$ & $29(56.86 \%)$ \\
$\begin{array}{l}\text { Grade I } \\
\text { Grade II }\end{array}$ & $16(31.37 \%)$ \\
Grade III & $6(11.76 \%)$ \\
\hline $\begin{array}{l}\text { Frequency of } \\
\text { Violence }\end{array}$ & $30(28.57 \%)$ \\
$\begin{array}{l}\text { Daily } \\
\text { Weekly } \\
\text { Monthly }\end{array}$ & $51(48.57 \%)$ \\
\hline $\begin{array}{l}\text { Perpetrator } \\
\text { Violence }\end{array}$ & $24(22.85 \%)$ \\
Husband & $90(85.71 \%)$ \\
Mother-in- law & $31(29.52 \%)$ \\
Sister-in-law & $5(4.76 \%)$ \\
\hline $\begin{array}{l}\text { Retaliation } \\
\text { Yes } \\
\text { No }\end{array}$ & $54(51.43 \%)$ \\
\hline
\end{tabular}

Table 3: Perceived Risk Factors *

\begin{tabular}{|l|l|}
\hline Factor & \\
\hline Addiction & $29(27.61 \%)$ \\
\hline Poverty & $31(29.52 \%)$ \\
\hline Son Preference & $19(18.09 \%)$ \\
\hline Childlessness & $2(1.904 \%)$ \\
\hline Dowry Extra-marital & $4(3.809 \%)$ \\
\hline $\begin{array}{l}\text { Husband's } \\
\text { Relation }\end{array}$ & $13(12.38 \%)$ \\
\hline Unemployment of husband & $14(13.33 \%)$ \\
\hline Chronic illness of husband & $4(3.809 \%)$ \\
\hline Others & $25(23.80 \%)$ \\
\hline
\end{tabular}

Others included Hot tempered husbands, Male dominance.

* Multiple responses.

Table 4 :Triggering factors*

\begin{tabular}{|l|l|}
\hline Factor & \\
\hline Not giving food in time & $32(30.47 \%)$ \\
\hline Not cooking properly & $21(20 \%)$ \\
\hline $\begin{array}{l}\text { Not taking care of house \& } \\
\text { children }\end{array}$ & $22(20.95 \%)$ \\
\hline On asking for money & $33(31.42 \%)$ \\
\hline Dis respect of in - laws. & $12(11.42 \%)$ \\
\hline Others & $9(8.57 \%)$ \\
\hline
\end{tabular}

Others included Addiction, In- laws insticate.

* Multiple responses.

Table 5 :Health Profile of the study subjects

\begin{tabular}{|l|l|}
\hline Factor & Count \\
\hline Body ache & $32(30.48 \%)$ \\
\hline Backache \& Leucorrhoea & $12(11.43 \%)$ \\
\hline
\end{tabular}




\begin{tabular}{|l|l|}
\hline Weakness & $13(12.38 \%)$ \\
\hline URTI & $10(9.52 \%)$ \\
\hline Others & $20(19.05 \%)$ \\
\hline None & $18(17.14 \%)$ \\
\hline
\end{tabular}

Others included pallor, dizziness.

Table 6: Nutrition Status of women

\begin{tabular}{|l|l|l|l|}
\hline Nutrition Status & \multicolumn{2}{|l|}{ Age Group } & \\
\hline & $\mathbf{1 8}-\mathbf{2 5}$ years & $\mathbf{2 6}-\mathbf{4 5}$ years & Total \\
\hline Lower BMI & $18(47.37 \%)$ & $12(17.91 \%)$ & $30(28.57 \%)$ \\
\hline Normal BMI & $14(36.84 \%)$ & $39(58.21 \%)$ & $53(50.48 \%)$ \\
\hline Higher BMI & $6(15.79 \%)$ & $16(23.88 \%)$ & $22(20.95 \%)$ \\
\hline Total & $38(100 \%)$ & $67(100 \%)$ & $105(100 \%)$ \\
\hline
\end{tabular}

Table 7:Decision making Capacity of the women.

\begin{tabular}{|l|l|l|}
\hline & $\begin{array}{l}\text { Who decides what to } \\
\text { cook }\end{array}$ & $\begin{array}{l}\text { Who decides about purchasing } \\
\text { major house hold items }\end{array}$ \\
\hline Self & $84(80 \%)$ & $4(3.8 \%)$ \\
\hline Husband & $2(1.9 \%)$ & $74(70.48 \%)$ \\
\hline Both & $0(0 \%)$ & $13(12.38 \%)$ \\
\hline In Laws & $19(18.1 \%)$ & $14(13.34 \%)$ \\
\hline Total & $105(100 \%)$ & $105(100 \%)$ \\
\hline
\end{tabular}

Table 8: Decision making Capacity of women.

\begin{tabular}{|l|l|l|l|}
\hline & $\begin{array}{l}\text { Does husband } \\
\text { allow to keep } \\
\text { enough money }\end{array}$ & $\begin{array}{l}\text { Does husband } \\
\text { force to } \\
\text { leave/prevent } \\
\text { from taking job }\end{array}$ & $\begin{array}{l}\text { Do you need } \\
\text { permission for } \\
\text { going out of } \\
\text { home }\end{array}$ \\
\hline Yes & $49(46.67 \%)$ & $72(68.58 \%)$ & $34(32.38 \%)$ \\
\hline No & $56(53.33 \%)$ & $33(31.42 \%)$ & $71(67.62 \%)$ \\
\hline Total & $105(100 \%)$ & $105(100 \%)$ & $105(100 \%)$ \\
\hline
\end{tabular}

\section{Discussions}

All the women in the study (105) experienced violence. Most of them(54.14\%) belonged to the age group $26-35$ years which is similar to the study done by S. Mitra[3]. Many women who were illiterate ( $53.34 \%$ ) faced violence in this study comparable to study done by D Ghosh[4]. Housewives were affected more with violence in this study as compared to women who were working, similar to findings seen by D. Ghosh[4].

Common forms of violence were verbal (71.42\%) and physical violence (48.57\%). Most common form of physical violence faced by women was Grade I $(56.86 \%)$, followed by grade II(31.37\%) \& then Grade $\mathrm{III}(11.76 \%)$, and the perpetrators of violence were the women's husband $(85.71 \%)$ and mother in law $(29.52 \%)$ , similar to study done by Khosla. A. H[2]. The perceived risk factor were Poverty (21.9\%) \& Addiction in husbands(20\%), as seen in study done by S. Mitra[3]. The triggering factor for violence was not giving food in time $(26.67 \%)$ and asking for money $(26.67 \%)$. Women who experienced violence faced various health problems ranging from Bodyache to Leucorrhea. $28.5 \%$ of these women were also seen to have lower BMI, similar to study done by Ajay Kumar[5] The women in the study did not have much decision making power and were not allowed to keep money with themselves \& were not allowed to take decisions on purchasing major household items, as seen in study done by Acharya et. al[6].

\section{Conclusions}

The women included in this study were those who had experienced violence and attending the Urban Health Centre. Maximum(82.86\%) of these women were Muslims and belonged to the age group $26-35$ years. More than half of the respondents were illiterate and belonged to Nuclear families. The most common form of violence faced by these women were Verbal and Physical violence. The perpetrators of violence were mostly the victims husbands' and mother- in - law. The perceive risk factors were mostly Poverty and Addiction in Husbands'. The triggering factors were Not giving food in time and Asking for money. These women had various health problems ranging from Backache, Bodyache to Leucorrhea. Many of them even had a lower BMI.

The women in this study were even not allowed to take their own decision. They were not allowed to keep any money with themselves and were also forced to leave jobs, or were prevented from taking jobs.

\section{Recommendations}


Awareness should be created about provision of medical, psychological care, counseling and alcohol anonymous to tackle problem of addiction in men. Government programs to enhance education of women are already in place. Efforts should be put to increase awareness about this in women \& girls. Efficient screening program should be put in place at all health care providing facilities to detect cases of domestic violence based on the findings of this study. Health education and public awareness about problem of domestic violence should be done through Involvement of mass media and non-governmental organizations. Economic growth of women through schemes of self employment \& income generation should be boosted so as to ensure social \& health empowerment.

\section{References}

[1] National family health survey-3, 2005-06: Domestic Violence, pg. 503.

[2] Khosla A. H, Deepti Dua, Lajya Devi, Shyam Sunder Sud; Domestic violence in pregnancy in North Indian women. Indian J of Med Sci 2005; 59(5):195-199.

[3] Mitra S.; Domestic Violence along with its Socio cultural Determinants among Pregnant Women attending MCH Clinic of a Sub Divisional Hospital West Bengal. Indian Journal of Community Medicine,2006, 31(4), 267 - 269.

[4] Ghosh D.; Predicting Vulnerability of Indian Women to Domestic Violence Incidents; Research and Practice in Social Sciences, Vol.3, No.1 (Aug. 2007) 48-72.

[5] Domestic Violence in India and repercussion on Women's Health. Ajay Kumar, Rabindra kumar Sinha. Available at http://paa2004.princeton.edu/papers/41350. Accessed on 13th August 2008.

[6] Women's autonomy in household decision making: a demographic study in Nepal. Acharya D.R., Jacquelline S. Bell, Padam Simbhada, Edwin Rvan Teijlenjer, Pramod R. Ragmi. Available at http://www.ncbi.nlm.nih.gov/pubmed/20630107. Accessed on 15 th September 2011 . 